\title{
Enterovibrio norvegicus gen. nov., sp. nov., isolated from the gut of turbot (Scophthalmus maximus) larvae: a new member of the family Vibrionaceae
}

\footnotetext{
1,2 Laboratory for Microbiology ${ }^{1}$ and BCCM/LMG Bacteria Collection ${ }^{2}$, Ghent University, K. L. Ledeganckstraat 35, Ghent 9000, Belgium

${ }^{3}$ CIAD/Mazatlán Unit for Aquaculture, AP 711, Mazatlán, Sinaloa, Mexico 82000
}

\author{
F. L. Thompson, ${ }^{1,2}$ B. Hoste, ${ }^{2}$ C. C. Thompson, ${ }^{1}$ J. Goris, ${ }^{1}$ B. Gomez-Gil, ${ }^{1,3}$ \\ L. Huys, ${ }^{1}$ P. De $\operatorname{Vos}^{1}$ and J. Swings ${ }^{1,2}$
}

\begin{abstract}
Author for correspondence: F. L. Thompson. Tel: +329264 5238. Fax: +3292645092. e-mail: Fabiano.Thompson@rug.ac.be
\end{abstract}

\begin{abstract}
Twenty-two isolates originating from the gut of healthy cultured turbot larvae in Norway were investigated using a polyphasic approach. Amplified fragment length polymorphism fingerprinting analysis showed that the isolates have typical patterns and form two main groups. Phylogenetic analysis revealed that the isolates belong to the $\gamma$-Proteobacteria, with Vibrio hollisae as their closest neighbour. DNA-DNA hybridization, chemotaxonomic and phenotypic analyses further proved that these isolates represent a tight novel taxon that differs from currently described species in the family Vibrionaceae. It is proposed that these novel isolates be accommodated in a new genus, Enterovibrio gen. nov., with Enterovibrio norvegicus sp. nov. as the type species. Isolates were motile by a polar flagellum, positive for oxidase, catalase, arginine dihydrolase and $\beta$-galactosidase, but negative for the Voges-Proskauer reaction. They produced indole, did not reduce nitrate and were resistant to the vibriostatic agent $0 / 129$. The DNA G+C content of $E$. norvegicus was $47 \cdot 1-47.9 \mathrm{~mol} \%$. The type strain is $E$. norvegicus LMG $19839^{\top}$ (= CAIM 430').
\end{abstract}

Keywords: Vibrionaceae, Enterovibrio norvegicus gen. nov., sp. nov., gut microorganism, turbot ( $S$. maximus)

\section{INTRODUCTION}

Turbot (Scophthalmus maximus) is a commercially important species that has been intensively fished and reared in different continents. Recently, there have been several reports showing that the intestinal microflora of sea-water fish is dominated by members of the family Vibrionaceae and that the gut microflora plays an important role in the health of early life stages of fish (Hansen \& Olafsen, 1999; Ring \& Birkbeck,

Published online ahead of print on 12 July 2002 as DOI 10.1099/ ijs.0.02315-0.

Abbreviation: AFLP, amplified fragment length polymorphism.

The EMBL accession numbers for the 16S rDNA sequences of strains LMG 19839', LMG 19840 and LMG 19842 are respectively AJ316208, AJ316207 and AJ437193.

A list of less-common phenotypic reactions of members of the Vibrionaceae is available as supplementary data in IJSEM Online (http:// ijs.sgmjournals.org/).
1999). Mortalities in early larval stages of intensively cultured marine fish are often very high and related to bacterial infections in which opportunistic bacteria play an important role (Ishimura et al., 1996; Diggles et al., 2000). On the other hand, it has also been proved that certain Vibrio strains isolated from the gut of $S$. maximus larvae, when added to the culture water, improve larval survival and growth (Huys et al., 2001). Culturable microflora from the gut of fish larvae have been the subject of many reports, but these microorganisms have generally been identified only at the family and/or genus level (Blanch et al., 1997; Ring \& Gatesoupe, 1998). It is likely that phenotype-based fingerprinting techniques applied in many previous studies have hampered the correct taxonomic identification of several taxa (Cerdà-Cuéllar et al., 1997; Hansen \& Olafsen, 1999; Onarheim et al., 1994; Ring $\&$ Birkbeck, 1999). The usefulness of genomic fingerprinting techniques such as amplified fragment length polymorphism (AFLP), pulsed-field gel electro- 
phoresis and repetitive elements palindrome PCR for studies on bacterial evolution, phylogeny and taxonomy have recently been recognized (Rademaker et al., 2000; Van Belkum et al., 2001). Several researchers have also suggested that AFLP could be an alternative to whole-genome sequencing and DNA-DNA hybridization experiments (Coenye et al., 1999; Huys et al., 1996; Janssen, 2001).

In the present study, phenotypic and genomic features of 22 isolates from the gut of turbot larvae are described. It is also shown that, phenotypically, the isolates resemble the genus Vibrio, but at the genomic level they clearly represent a novel genus, for which the name Enterovibrio gen. nov. is proposed; Enterovibrio norvegicus sp. nov. is the type species.

\section{METHODS}

Twenty-two isolates [LMG $19839^{\mathrm{T}}$ (= CAIM 430 ${ }^{\mathrm{T}}$ ), LMG 19840 (= CAIM 427), LMG 19841 (= CAIM 436), LMG 19842 ( = CAIM 451), LMG 20957 (= CAIM 428), R-3719, R-3668, R-3678, R-3708, R-3717, R-3727, R-3729, R-3731, R-3749, R-3759, R-3764, R-3929, R-3773, R-3792, R-3814, $\mathrm{R}-3819$, R-3847], isolated from the gut of healthy turbot larvae at the Aquaculture Research Station of Austevoll (Norway) during the summer of 1997 as described previously (Huys et al., 2001), were analysed. All strains included in this study were deposited in the BCCM/LMG Bacteria Collection at Ghent University and in the CAIM collection of the Centre of Research on Nutrition and Development (CIAD) in Mazatlán, Mexico. Strains were grown on marine agar 2216E (MA; Difco) at $28^{\circ} \mathrm{C}$ for $24 \mathrm{~h}$ unless otherwise stated. Colony morphology was examined on cultures grown on thiosulfate-citrate-bile salts-sucrose agar (TCBS; Difco) and tryptone soy agar (TSA; Oxoid) supplemented with $2 \%(\mathrm{w} / \mathrm{v}) \mathrm{NaCl}$ using a stereoscopic microscope. Cell morphology was examined on wet mounts using a phasecontrast microscope.

Bacterial DNA was extracted following the technique of Pitcher et al. (1989). Fluorescent AFLP patterns and 16S rDNA sequences were generated on an ABI Prism 377 DNA sequencer (Applied Biosystems) and analysed as described previously (Thompson et al., 2001). The consensus sequences were transferred into BIONUMERICS 2.0 software (Applied Maths) and phylogenetic trees were constructed based on the neighbour-joining (Saitou \& Nei, 1987) and maximumparsimony methods. The $16 \mathrm{~S}$ rDNA sequences of the type strains of Vibrio ichthyoenteri and Vibrio penaeicida were determined in the course of the present study. The $16 \mathrm{~S}$ rDNA sequences of the other type strains included in this study were retrieved from the EMBL database. DNA-DNA hybridization was performed under stringent conditions using the microplate technique with photobiotin-labelled DNA at a temperature of $38^{\circ} \mathrm{C}$ for $3 \mathrm{~h}$, as described previously (Willems et al., 2001). The DNA G + C content was determined by HPLC (Tamaoka \& Komagata, 1984).

Phenotypic characterization of the isolates was performed using API 20E, API ZYM (bioMérieux) and Biolog GN metabolic fingerprinting following the instructions of the manufacturers, with slight modifications (Thompson et al., 2002). Classical phenotypic tests were performed as described previously (Baumann et al., 1984; Delafield et al., 1965; Farmer \& Hickman-Brenner, 1992; Thompson et al., 2002; Vandamme et al., 1998). Antibiograms were carried out using disc diffusion methodology (Acar \& Goldstein,
1996) with commercial discs (Oxoid). The inhibition zone of each antibiotic was measured on strains grown on brainheart infusion broth (BHI; Difco) supplemented with $1.5 \%$ (w/v) bacteriological agar no. 1 (Oxoid) and with $1.5 \%$ (w/v) $\mathrm{NaCl}$ for $24 \mathrm{~h}$ at $28^{\circ} \mathrm{C}$. Fatty acid methyl ester analysis was carried out as described by Huys et al. (2001). Isolates were grown on trypticase soy broth (Becton Dickinson) supplemented with $1.5 \%(\mathrm{w} / \mathrm{v})$ Bacto agar (Becton Dickinson) and $1.5 \%(\mathrm{w} / \mathrm{v}) \mathrm{NaCl}$ and on MA at $28{ }^{\circ} \mathrm{C}$ for $24 \mathrm{~h}$. Approximately $50 \mathrm{mg}$ cells was harvested and the fatty acids were isolated and analysed using the Microbial Identification System software package, version 3.9 (Microbial ID).

\section{RESULTS AND DISCUSSION}

Fingerprinting analysis of the whole genome from the novel isolates representing Enterovibrio gen. nov. clearly showed that they possess typical AFLP patterns consisting of $78 \pm 9$ bands (Fig. 1). Intraspecific genomic diversity exists among the 22 isolates, and at least two main groups of genomes exist, corresponding to AFLP clusters A68 and A69 found in a previous study (Thompson et al., 2001). Some isolates (R-3749, R-3847 and R-3773; R-3717 and R-3929; R-3731 and R-3668; LMG 19841 and R-3708; R-3719 and LMG $19839^{\mathrm{T}}$ ) clustered at the reproducibility level (i.e. $\geqslant 88 \%$ pattern similarity) and were thus indistinguishable by AFLP. Visual examination and numerical analysis of the AFLP patterns of the Enterovibrio isolates revealed that they form a cluster that is completely separate from currently known species in the family Vibrionaceae (Thompson et al., 2001), supporting our conclusion that Enterovibrio species possess a unique genome.

Fig. 2 shows a neighbour-joining tree with the estimated positions of most representatives of the Vibrionaceae and bootstrap values after 500 simulations, based on almost complete 16S rDNA sequences. Six main branches could be distinguished within this family by both neighbour-joining and maximum-parsimony methods. The first branch harboured the Enterovibrio isolates. Vibrio hollisae formed a second branch sharing only $94 \% 16 \mathrm{~S}$ rDNA similarity with Enterovibrio gen. nov., its closest neighbour. The $16 \mathrm{~S}$ rDNA sequences of these two taxa clearly indicate that they represent two new genera within the family Vibrionaceae. It has been previously concluded that $95-96 \% 16 \mathrm{~S}$ rDNA similarity is the level for circumscribing different genera within the family Vibrionaceae (Kita-Tsukamoto et al., 1993). It has been suggested that $V$. hollisae should be elevated to genus rank because of its great divergence from other Vibrio species (Dorsch et al., 1992; KitaTsukamoto et al., 1993). The third branch harboured the Photobacterium species, which had 16S rDNA sequence similarity values of $93.9-97.8 \%$. The fourth branch consisted of the psychrophilic species Vibrio fischeri, Vibrio wodanis, Vibrio salmonicida and Vibrio logei, which had similarities of $95 \cdot 2-98 \cdot 3 \%$. The fifth branch harboured all other Vibrio species (except $V$. hollisae), Listonella pelagia and Listonella anguillarum, 


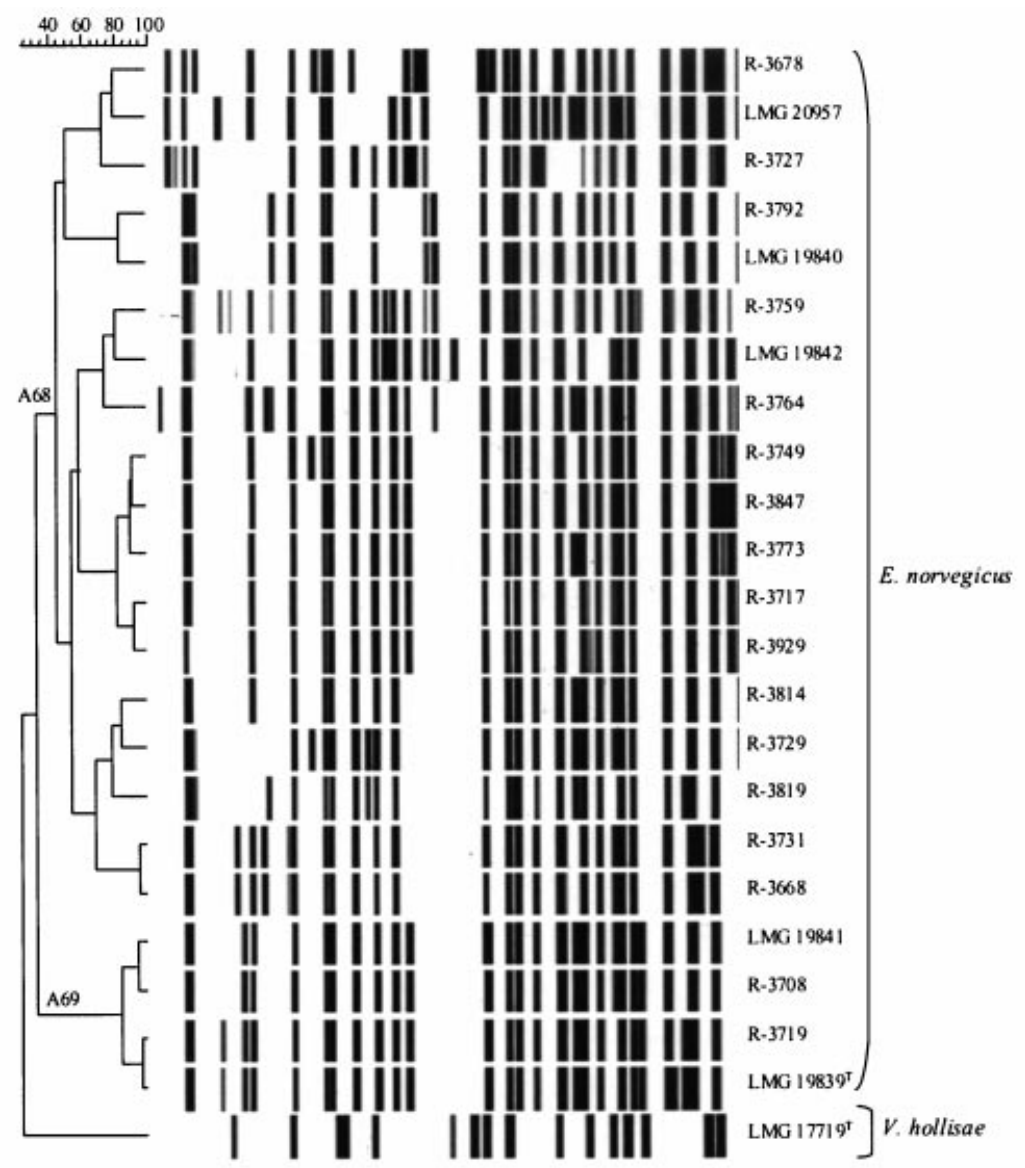

Fig. 1. Dendrogram of the AFLP patterns of 22 isolates of Enterovibrio norvegicus gen. nov., sp. nov. Vibrio hollisae LMG 17719', the closest phylogenetic neighbour of $E$. norvegicus, was included as an outlier. A band-based (Dice) cluster analysis (Ward) was used. which had similarities of 92.9-99.2 \% . Enterovibrio was distantly related to Vibrio cholerae, the type species of the family Vibrionaceae, sharing only $91.6 \% 16 \mathrm{~S}$ rDNA similarity. Some members of the fourth branch have been referred to as the Vibrio core group (Dorsch et al., 1992). It is noticeable that this branch is quite diverse. The genus Listonella, which was proposed based on the 5S rDNA sequence (Macdonell \& Colwell, 1985), cannot be distinguished from the other vibrios. The $16 \mathrm{~S}$ rDNA sequences of $V$. ichthyoenteri LMG $19664^{\mathrm{T}}$ and $V$. penaeicida LMG $19663^{\mathrm{T}}$, determined in this study, belonged to the fifth branch and were respectively closely related to Vibrio scophthalmi $(99 \cdot 2 \%)$ and Vibrio nigripulchritudo (97.2\%). Salinivibrio costicola formed the sixth branch, having 92.6\% similarity to the Enterovibrio isolates. The $16 \mathrm{~S}$ rDNA similarities of Enterovibrio isolates towards representative species of related genera, Shewanella benthica (X82131), Moritella marina (X74711) and Pseudoalteromonas haloplanktis (X67024) were respectively $90 \cdot 7,89.5$ and $89 \cdot 1 \%$. Based on $16 \mathrm{~S}$ rDNA similarity values among the Enterovibrio isolates and other members of the family Vibrionaceae, it can be concluded that the Enterovibrio isolates represent a new taxon in this family.

DNA-DNA hybridization experiments revealed that the Enterovibrio isolates form a single tightly related group that exhibits at least $87 \%$ DNA similarity
(Table 1). Enterovibrio showed only $22 \%$ DNA similarity with its closest phylogenetic neighbour, $V$. hollisae. These results confirmed our findings from AFLP and 16S rDNA sequence analyses and proved that the Enterovibrio isolates should be regarded as a novel taxon. The Enterovibrio isolates possessed DNA $\mathrm{G}+\mathrm{C}$ contents of $47 \cdot 1-47.9 \mathrm{~mol} \%$.

The Enterovibrio isolates shared the main phenotypic features of the genus Vibrio. However, some characteristics useful in differentiating Enterovibrio from other genera of the family Vibrionaceae were found and are listed in Table 2 (a list of less-common phenotypic reactions of members of the Vibrionaceae is available as supplementary data in IJSEM Online; http://ijs.sgmjournals.org/). The novel species is easily differentiated from Photobacterium and Salinivibrio species since it produces indole but not acetoin. It can also be distinguished from Salinivibrio strains by its $\beta$ galactosidase activity and the absence of gelatinase activity. Most vibrios reduce nitrate (except Vibrio cyclitrophicus, Vibrio gazogenes, Vibrio metschnikovii and $V$. salmonicida) and utilize pyruvate (except Vibrio halioticoli and Vibrio tapetis), whereas the Enterovibrio isolates do not. Moreover, Enterovibrio is not susceptible to the vibriostatic agent $\mathrm{O} / 129$, unlike most vibrios (except Vibrio lentus and Vibrio aerogenes). The $\mathrm{G}+\mathrm{C}$ contents of the DNA of the Enterovibrio isolates partially overlap the $\mathrm{G}+\mathrm{C}$ contents of vibrios. 


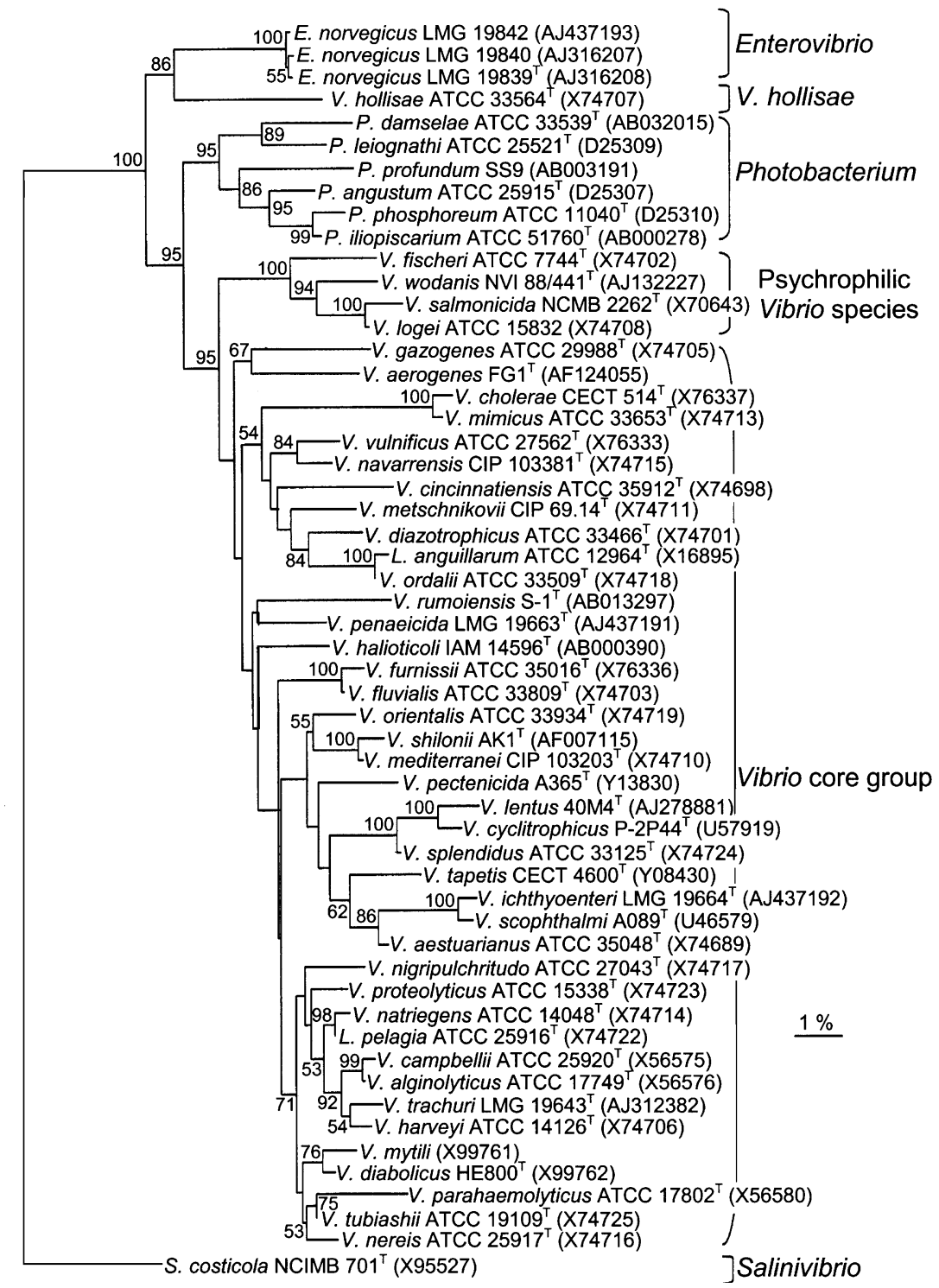

Fig. 2. Phylogenetic tree with the estimated positions of most representatives of the family Vibrionaceae using the neighbourjoining method based on almost complete $16 \mathrm{~S}$ rDNA sequences. Bootstrap percentages after 500 simulations are shown. Bar, 1\% estimated sequence divergence.

Table 1. DNA similarity among $E$. norvegicus isolates and $V$. hollisae LMG $17719^{\top}$ and their $\mathrm{G}+\mathrm{C}$ content

\begin{tabular}{|c|c|c|c|c|c|c|c|}
\hline \multirow[t]{2}{*}{ Strain } & \multirow{2}{*}{$\begin{array}{c}\mathrm{G}+\mathrm{C} \text { content } \\
(\mathrm{mol} \%)\end{array}$} & \multicolumn{6}{|c|}{ DNA similarity (\%) with: } \\
\hline & & 1 & 2 & 3 & 4 & 5 & 6 \\
\hline \multicolumn{8}{|c|}{ E. norvegicus gen. nov., sp. nov. } \\
\hline 1. LMG 19840 & $47 \cdot 9$ & 100 & & & & & \\
\hline 2. LMG 20957 & $47 \cdot 1$ & 94 & 100 & & & & \\
\hline 3. LMG $19839^{\mathrm{T}}$ & $47 \cdot 5$ & 87 & 103 & 100 & & & \\
\hline 4. LMG 19841 & $47 \cdot 4$ & 92 & 104 & 99 & 100 & & \\
\hline 5. LMG 19842 & 47.6 & 91 & 99 & 91 & 92 & 100 & \\
\hline \multicolumn{8}{|l|}{ V. hollisae } \\
\hline 6. LMG $17719^{\mathrm{T}}$ & $48 \cdot 5$ & 20 & 21 & 22 & 22 & 21 & 100 \\
\hline
\end{tabular}


Table 2. Useful features for differentiating genera in the family Vibrionaceae

Data were obtained from Alsina \& Blanch (1994), Benediktsdóttir et al. (2000), Borrego et al. (1996), Hedlund \& Staley (2001), Ishimaru et al. (1995), Ishimaru et al. (1996), Lambert et al. (1998), Macián et al. (2001), Onarheim et al. (1994), Pujalte et al. (1993), Raguénès et al. (1997), Sawabe et al. (1998), Urdaci et al. (1991) and Yumoto et al. (1999). A list of less-common phenotypic reactions of members of the Vibrionaceae is available as supplementary material in IJSEM Online (http://ijs.sgmjournals.org/).

\begin{tabular}{|c|c|c|c|c|}
\hline Characteristic & Enterovibrio & Photobacterium & Salinivibrio & Vibrio \\
\hline ONPG & + & $+*$ & - & $+*$ \\
\hline Gelatinase activity & - & $-\dagger$ & + & $+^{*}$ \\
\hline Acetoin production & - & $+*$ & + & $-\dagger$ \\
\hline Indole production & + & - & - & $+^{*}$ \\
\hline Arginine dihydrolase & + & + & + & $-*$ \\
\hline Nitrate reduction & - & $+*$ & - & $+\dagger$ \\
\hline Susceptibility to O/129 (150 $\mu \mathrm{g})$ & - & + & + & $+\dagger$ \\
\hline \multicolumn{5}{|l|}{ Utilization of: } \\
\hline Citrate & - & - & - & $+*$ \\
\hline Pyruvate & - & $+\dagger$ & + & $+\dagger$ \\
\hline Propionate & - & - & + & $+*$ \\
\hline L-Proline & - & $-\dagger$ & + & $+\dagger$ \\
\hline D-Alanine & - & & + & $+\dagger$ \\
\hline Aconitate & - & & - & $+\dagger$ \\
\hline DNA G + C content $(\mathrm{mol} \%)$ & $47 \cdot 1-47 \cdot 9$ & $40 \cdot 0-44 \cdot 0$ & $49 \cdot 0-50 \cdot 5$ & $38 \cdot 8-50 \cdot 6 \%$ \\
\hline
\end{tabular}

* Over $65 \%$ of species show this feature (exceptions are listed in the supplementary material). $\dagger$ Over $85 \%$ of species show this feature.

$\ddagger$ Over $65 \%$ of species have $\mathrm{G}+\mathrm{C}$ contents that are not within the range $47-48 \mathrm{~mol} \%$.

The Enterovibrio isolates possess typical fatty acid patterns and phenotypic features that differentiate them from other arginine dihydrolase- and indolepositive species of the family Vibrionaceae (Table 3).

The genomic and phenotypic features of the Enterovibrio isolates presented in this study clearly prove that these isolates represent a novel taxon within the family Vibrionaceae. Therefore, it is proposed to include these isolates into a new genus, Enterovibrio gen. nov., with Enterovibrio norvegicus sp. nov. as the type species.

\section{Description of Enterovibrio gen. nov.}

Enterovibrio (En.te.ro.vib'ri.o. Gr. n. enteron intestine; L. n. vibrio that which vibrates; N.L. n. Enterovibrio enteric vibrio).

Gram-negative, motile, oxidase- and catalase-positive. DNA G $+C$ content of $47 \cdot 1-47 \cdot 9 \%$. The most abundant fatty acids are $16: 1 \omega 7 c$ and/or $15: 0$ iso $2-\mathrm{OH}$, 16:0 and 18:1 $107 c$. Chemoheterotrophic, mesophilic and moderately halophilic. Enterovibrio strains utilize dextrin, $N$-acetyl D-glucosamine and $\alpha$-D-glucose as sole carbon sources. Arginine dihydrolase, indole and $\beta$-galactosidase are positive. Voges-Proskauer and lysine and ornithine decarboxylases are negative. Nitrate is not reduced. Resistant to the vibriostatic agent $\mathrm{O} / 129(10$ and $150 \mu \mathrm{g})$. Member of the $\gamma$ Proteobacteria. Type species is Enterovibrio norvegicus.

\section{Description of Enterovibrio norvegicus sp. nov.}

Enterovibrio norvegicus (nor.ve'gi.cus. M.L. adj. norvegicus of Norway, where the organism was isolated).

Description is as for the genus with the following additional features. Cells are $0.8 \times 1 \cdot 0-1.2 \mu \mathrm{m}$ and motile by means of a polar flagellum when grown in liquid medium. They form smooth, rounded colonies with raised margins, beige in colour and about $1 \mathrm{~mm}$ in diameter after 2 days incubation on MA at $27-28{ }^{\circ} \mathrm{C}$. These facultative anaerobic isolates also grow well on TSA and BHI agar supplemented with $1.5 \% \mathrm{NaCl}$. The isolates grow slowly on TCBS, forming green colonies after 3 days at $28^{\circ} \mathrm{C}$. No growth occurs in the absence of $\mathrm{NaCl}$ or with $\geqslant 8.0 \% \mathrm{NaCl}$. No growth occurs at 4 or $\geqslant 35^{\circ} \mathrm{C}$. Prolific growth occurs in media containing $2 \% \mathrm{NaCl}$ at $20-28^{\circ} \mathrm{C}$. Has both an oxidative and a fermentative metabolism. Aerobic utilization of different carbon sources is summarized in Table 4. All strains ferment $\alpha$-D-glucose. None of the strains ferment arabinose, amygdalin, melibiose, sucrose, L-rhamnose, D-sorbitol, myo-inositol or Dmannitol. Produces $\beta$-galactosidase, alkaline phosphatase, esterase, esterase lipase, lipase, leucine arylamidase, acid phosphatase and naphthol-AS-BIphosphohydrolase, but not tryptophan deaminase, urease, gelatinase, DNase, valine arylamidase, cystine arylamidase, trypsin, chymotrypsin, $\alpha$-galactosidase, 
Table 3. Useful features for differentiating arginine dihydrolase- and indole-positive species of the family Vibrionaceae

Taxa: 1, E. norvegicus gen. nov., sp. nov. $(n=22) ; 2, V$. aestuarianus $(n=3) ; 3, V$. anguillarum $(n=3) ; 4, V$. diazotrophicus $(n=3) ; 5, V$. fluvialis $(n=2) ; 6, V$. furnissii $(n=2) ; 7, V$. mediterranei $(n=5) ; 8, V$. metschnikovii $(n=3) ; 9, V$. mimicus $(n=1) ; 10, V$. nereis $(n=3) ; 11$, V. orientalis $(n=2) ; 12, V$. proteolyticus $(n=2) ; 13, V$. splendidus $(n=1) ; 14, V$. tubiashii $(n=3) ; 15$, P. damselae subsp. damselae $(n=2)$. ND, Not detected; v, variable; empty cells, no data available. Phenotypic data were obtained from this study and from Alsina \& Blanch (1994). V. diazotrophicus, V. mediterranei, V. metschnikovii, V. mimicus, V. orientalis, V. splendidus and V. tubiashii have variable arginine dihydrolase reactions.

\begin{tabular}{|c|c|c|c|c|c|c|c|c|c|c|c|c|c|c|c|}
\hline Feature & 1 & 2 & 3 & 4 & 5 & 6 & 7 & 8 & 9 & 10 & 11 & 12 & 13 & 14 & 15 \\
\hline \multicolumn{16}{|l|}{ Fatty acid methyl esters $(\%): *$} \\
\hline 14:0 & $2 \cdot 7 \pm 0 \cdot 8$ & $5.5 \pm 0 \cdot 7$ & $5 \cdot 6 \pm 0 \cdot 7$ & $4 \cdot 0 \pm 1 \cdot 0$ & $3 \cdot 6 \pm 0 \cdot 3$ & $4 \cdot 0 \pm 0 \cdot 3$ & $8 \cdot 3 \pm 1 \cdot 8$ & $5 \cdot 1 \pm 0 \cdot 5$ & $4 \cdot 1$ & $5 \cdot 4 \pm 0 \cdot 5$ & $10 \cdot 0 \pm 5 \cdot 6$ & $3 \cdot 5 \pm 0 \cdot 3$ & $9 \cdot 4$ & $4 \cdot 9 \pm 1 \cdot 0$ & $5 \cdot 7 \pm 1 \cdot 5$ \\
\hline $16: 0$ & $20 \cdot 9 \pm 1 \cdot 5$ & $23 \cdot 1 \pm 1$ & $27 \cdot 2 \pm 2 \cdot 8$ & $21 \cdot 7 \pm 2 \cdot 8$ & $14 \cdot 3 \pm 2 \cdot 5$ & $14 \cdot 8 \pm 2 \cdot 3$ & $18 \cdot 1 \pm 3 \cdot 0$ & $19 \cdot 2 \pm 1 \cdot 1$ & 21 & $14 \cdot 3 \pm 2 \cdot 8$ & $21 \cdot 2 \pm 6 \cdot 1$ & $14 \cdot 6 \pm 0 \cdot 6$ & $27 \cdot 7$ & $17 \cdot 9 \pm 0.6$ & $18 \cdot 5 \pm 2 \cdot 7$ \\
\hline $16: 1 \omega 9 c$ & $3 \cdot 5 \pm 0 \cdot 3$ & ND & $1 \cdot 2 \pm 0 \cdot 4$ & ND & ND & ND & ND & ND & $1 \cdot 2$ & $0 \cdot 4$ & ND & $0 \cdot 4 \pm 0 \cdot 0$ & ND & 0.6 & ND \\
\hline $18: 1 \omega 9 c$ & $2 \cdot 7 \pm 0 \cdot 2$ & ND & ND & $0 \cdot 1$ & $0 \cdot 2$ & 0.3 & ND & $0 \cdot 3 \pm 0 \cdot 1$ & 0.7 & 0.2 & ND & $0 \cdot 2$ & $5 \cdot 3$ & $0 \cdot 4$ & ND \\
\hline $18: 1 \omega 7 c$ & $15 \cdot 0 \pm 2 \cdot 0$ & $16 \cdot 1 \pm 0 \cdot 6$ & $12 \cdot 3 \pm 0 \cdot 2$ & $17.5 \pm 0.9$ & $17.8 \pm 1.5$ & $22 \cdot 2 \pm 0 \cdot 0$ & $20 \cdot 8 \pm 2 \cdot 5$ & $22.8 \pm 0.6$ & $16 \cdot 2$ & $23 \cdot 1 \pm 1 \cdot 5$ & $22 \cdot 4 \pm 10 \cdot 8$ & $15 \cdot 5 \pm 1 \cdot 4$ & 12 & $23 \cdot 7 \pm 2 \cdot 6$ & $16 \cdot 4 \pm 6 \cdot 0$ \\
\hline ONPG & + & $\mathrm{v}^{*}$ & + & + & $\mathrm{v}$ & + & $\mathrm{v}$ & $\mathrm{v}$ & + & - & $-*$ & - & $\mathrm{v}$ & + & + \\
\hline Gelatinase activity & - & + & + & - & + & + & + & + & + & $\mathrm{v}$ & + & $\mathrm{v}$ & + & + & - \\
\hline Acetoin production & - & - & + & - & - & - & $\mathrm{v}$ & $\mathrm{v}$ & $\mathrm{v}$ & - & - & $\mathrm{v}$ & - & - & + \\
\hline Nitrate reduction & - & + & + & + & + & + & - & - & + & + & + & + & + & + & + \\
\hline Susceptibility to $\mathrm{O} / 129(150 \mu \mathrm{g})$ & - & + & + & + & + & + & - & + & - & + & & $\mathrm{v}$ & - & + & + \\
\hline Utilization of D-mannitol & $\mathrm{v} \dagger$ & + & + & + & + & + & $\mathrm{v}$ & $\mathrm{v}$ & $\mathrm{v}$ & $\mathrm{v}$ & + & $\mathrm{v}$ & + & + & - \\
\hline Acid from sucrose & - & + & + & + & + & + & + & + & - & + & + & - & $\mathrm{v}$ & + & $\mathrm{v}$ \\
\hline \multicolumn{16}{|l|}{ Growth on/at: } \\
\hline $8 \% \mathrm{NaCl}$ & - & $\mathrm{v}$ & - & + & $\mathrm{v}$ & + & $\mathrm{v}$ & $\mathrm{v}$ & - & + & + & + & $\mathrm{v}$ & $\mathrm{v}$ & $\mathrm{v}$ \\
\hline $35^{\circ} \mathrm{C}$ & - & + & + & + & + & + & $\mathrm{v}$ & + & + & + & + & + & $\mathrm{v}$ & $\mathrm{v}$ & \\
\hline
\end{tabular}

* Our own data.

$\dagger 95 \%$ of the Enterovibrio isolates do not utilize D-mannitol. 
Table 4. Variable phenotypic features of the $E$. norvegicus isolates

All isolates utilized dextrin, $N$-acetyl D-glucosamine and $\alpha$-D-glucose as sole carbon sources.

None of the isolates utilized $\alpha$-cyclodextrin, $N$-acetyl D-galactosamine, adonitol, L-arabinose, Darabitol, cellobiose, $i$-erythritol, $\mathrm{L}$-fructose, D-galactose, $\alpha$-D-lactose, lactulose, $\mathrm{D}$-melibiose, methyl $\beta$-D-glucoside, D-raffinose, L-rhamnose, methyl pyruvate, mono-methyl succinate, cisaconitic acid, citric acid, formic acid, D-galactonic acid, D-galacturonic acid, $\gamma$-hydroxybutyric acid, $p$-hydroxyphenylacetic acid, itaconic acid, $\alpha$-ketobutyric acid, $\alpha$-ketovaleric acid, malonic acid, propionic acid, quinic acid, D-saccharic acid, bromosuccinic acid, succinamic acid, glucuronamide, alaninamide, D-alanine, glycyl-L-glutamic acid, L-histidine, hydroxy L-proline, Lleucine, L-ornithine, L-phenylalanine, L-pyroglutamic acid, D-serine, $\gamma$-aminobutyric acid, urocanic acid, phenylethylamine, putrescine, 2-aminoethanol, 2,3-butanediol, glycerol or glycerol phosphate.

\begin{tabular}{|lcc|}
\hline Substrate & $\begin{array}{c}\text { E. norvegicus } \\
(\boldsymbol{n}=\mathbf{2 2})^{*}\end{array}$ & LMG 19839 $^{\mathbf{T}}$ \\
\hline D-Mannose & 16 & + \\
Maltose, acetic acid & 15 & + \\
Inosine & 14 & - \\
D-Trehalose & 12 & + \\
D-Fructose & 12 & - \\
Uridine & 9 & - \\
L-Alanine & 8 & - \\
L-Glutamic acid & 6 & - \\
$\beta$-Hydroxybutyric acid & 5 & + \\
DL-Lactic acid & 4 & - \\
Psicose & 4 & - \\
Malonic acid, succinic acid, gentiobiose & 2 & \\
Glycogen, D-mannitol, D-sorbitol, D-galacturonic acid, & 1 & \\
L-alanyl-glycine, L-asparagine, thymidine & & \\
\hline
\end{tabular}

* Numbers of positive isolates are given.

$\beta$-glucuronidase, $\mathrm{H}_{2} \mathrm{~S}$ or acetoin. Is not luminescent and is methyl red-negative and does not degrade poly(hydroxybutyrate). Resistant to the vibriostatic agent $\mathrm{O} / 129$ at 10 and $150 \mu \mathrm{g}$, streptomycin $(10 \mu \mathrm{g})$, trimethoprim $(1 \cdot 2 \mu \mathrm{g})$ and fusidic acid $(10 \mu \mathrm{g})$. Intermediate susceptibility to penicillin $\mathrm{G}(10 \mathrm{U})$, novobiocin $(5 \mu \mathrm{g})$, chloramphenicol $(30 \mu \mathrm{g})$, polymixin $\mathrm{B}$ $(300 \mathrm{U})$, ampicillin $(10 \mu \mathrm{g})$, oxytetracycline $(30 \mu \mathrm{g})$ and nalidixic acid $(30 \mu \mathrm{g})$. The major fatty acids of isolates grown on TSA/MA are summed feature 3 (35.8 \pm $0 \cdot 5 / 36 \cdot 2 \pm 0 \cdot 9 \%$; comprising $16: 1 \omega 7 c$ and/or $15: 0$ iso $2-\mathrm{OH}), 16: 0(20 \cdot 9 \pm 1 \cdot 5 / 19 \cdot 3 \pm 0 \cdot 7 \%), 18: 1 \omega 7 c$ $(15 \cdot 0 \pm 2 \cdot 0 / 14 \cdot 8 \pm 1 \cdot 1 \%), 12: 0(4 \cdot 2 \pm 0 \cdot 6 / 3 \cdot 4 \pm 0 \cdot 2 \%)$, $16: 1 \omega 9 c(3 \cdot 5 \pm 0 \cdot 3 / 3 \cdot 1 \pm 0 \cdot 2 \%), 16: 0$ iso $(2 \cdot 9 \pm 1 \cdot 8 /$ $2 \cdot 6 \pm 0.5 \%), \quad 14: 0 \quad(2 \cdot \overline{7} \pm 0 \cdot 8 / 1 \cdot 3 \pm 0 \cdot 2 \%), \quad 18: 1 \omega 9 c$ $(2 \cdot 7 \pm 0 \cdot 2 / 3 \cdot 1 \pm 0 \cdot 2 \%)$, summed feature $2(2 \cdot 5 \pm 0 \cdot 4 /$ $2 \cdot 4 \pm 0.2 \%$; comprising 14:0 $3-\mathrm{OH}$ and/or $16: 1$ iso I and/or an unidentified fatty acid with equivalent chain length of 10.928 and/or 12:0 ALDE), 12:0 3-OH $(1 \cdot 9 \pm 0 \cdot 4 / 2 \cdot 9 \pm 0 \cdot 2 \%), 18: 0(1 \cdot 8 \pm 0 \cdot 5 / 2 \cdot 4 \pm 0 \cdot 2 \%)$, an unidentified fatty acid with equivalent chain length of 12.484 (TSA only: $1 \cdot 1 \pm 0 \cdot 2 \%$ ), summed feature 7 (TSA only: $0 \cdot 9 \pm 0 \cdot 3 \% ; 19: 1 \omega 6 c$ and/or an unidentified fatty acid with equivalent chain-length value of 18.846), 14:0 iso (TSA only: 0.6 $\pm 0 \cdot 5 \%$ ), 17:1 $1 \omega 8 c$ (MA only: $2 \cdot 1 \pm 0 \cdot 2 \%$ ), 17:0 (MA only: $1 \cdot 4 \pm 0 \cdot 2 \%$ ) and 18:0 iso (MA only: $1 \cdot 0 \pm 0 \cdot 1 \%$ ). Isolated from the gut of larvae of the turbot (Scophthalmus maximus). The DNA $\mathrm{G}+\mathrm{C}$ content of the type strain is $47.7 \mathrm{~mol} \%$. The type strain is strain LMG $19839^{\mathrm{T}}$ (= CAIM $430^{\mathrm{T}}$ ).

\section{ACKNOWLEDGEMENTS}

F.L.T. has a PhD scholarship (no. 2008361/98-6) from Conselho Nacional de Desenvolvimento Científico e Tecnológico (CNPq), Brazil. J.S. has a personnel grant from the Fund for Scientific Research (FWO), Belgium. J. G. was supported by a grant ' Concerted Research Action 12050797' from FWO, Belgium. The authors thank the reviewers for their comments.

\section{REFERENCES}

Acar, J. F. \& Goldstein, F. W. (1996). Disc susceptibility test. In Antibiotics in Laboratory Medicine, 4th edn, pp. 1-51. Edited by V. Lorian. Baltimore: Williams \& Wilkins.

Alsina, M. \& Blanch, A. R. (1994). A set of keys for the biochemical identification of environmental Vibrio species. J Appl Bacteriol 76, 79-85.

Blanch, A., Alsina, M., Simon, M. \& Jofre, J. (1997). Determination of bacteria associated with reared turbot (Scophthalmus maximus) larvae. J Appl Microbiol 82, 729-734.

Baumann, P., Furniss, A. L. \& Lee, J. V. (1984). Genus I. Vibrio Pacini $1854,411^{\mathrm{AL}}$. In Bergey's Manual of Systematic Bacteriology, vol. 1, pp. 
518-538. Edited by N. R. Krieg \& J. G. Holt. Baltimore: Williams \& Wilkins.

Benediktsdóttir, E., Verdonck, L., Spröer, C., Helgason, S. \& Swings, J. (2000). Characterization of Vibrio viscosus and Vibrio wodanis isolated at different geographical locations: a proposal for reclassification of Vibrio viscosus as Moritella viscosa comb. nov. Int J Syst Evol Microbiol 50, 479-488.

Borrego, J. J., Castro, D., Luque, A., Paillard, C., Maes, P., Garcia, M. T. \& Ventosa, A. (1996). Vibrio tapetis sp. nov., the causative agent of the brown ring disease affecting cultured clams. Int $J$ Syst Bacteriol 46, 480-484.

Cerdà-Cuéllar, M., Rosselló-Mora, R. A., Lalucat, J., Jofre, J. \& Blanch, A. (1997). Vibrio scophthalmi sp. nov., a new species from turbot (Scophthalmus maximus). Int J Syst Bacteriol 47, 58-61.

Coenye, T., Schouls, L. M., Govan, J. R. W., Kersters, K. \& Vandamme, P. (1999). Identification of Burkholderia species and genomovars from cystic fibrosis patients by AFLP fingerprinting. Int $J$ Syst Bacteriol 49, 1657-1666.

Delafield, F. P., Doudoroff, M., Palleroni, N. J., Lusty, C. J. \& Contopoulos, R. (1965). Decomposition of poly- $\beta$-hydroxybutyrate by pseudomonads. J Bacteriol 90, 1455-1466.

Diggles, B. K., Carson, J., Hine, P. M., Hickman, R. W. \& Tait, M. J. (2000). Vibrio species associated with mortalities in hatchery-reared turbot (Colistium nudipinnis) and brill (C. guntheri) in New Zealand. Aquaculture 183, 1-12.

Dorsch, M., Lane, D. \& Stackebrandt, E. (1992). Towards a phylogeny of the genus Vibrio based on $16 \mathrm{~S}$ rRNA sequences. Int J Syst Bacteriol 42, 58-63.

Farmer, J. J., III \& Hickman-Brenner, F. W. (1992). The genera Vibrio and Photobacterium. In The Prokaryotes. A Handbook on the Biology of Bacteria: ecophysiology, Isolation, Identification, and Applications, 2nd edn, pp. 2952-3011. Edited by A. Balows, H. G. Trüper, M. Dworkin, W. Harder \& K.-H. Schleifer. New York: Springer.

Hansen, G. H. \& Olafsen, J. A. (1999). Bacterial interactions in early life stages of marine cold water fish. Microb Ecol 38, 1-26.

Hedlund, B. P. \& Staley, J. T. (2001). Vibrio cyclotrophicus sp. nov., a polycyclic aromatic hydrocarbon (PAH)-degrading marine bacterium. Int J Syst Evol Microbiol 51, 61-66.

Huys, G., Coopman, R., Janssen, P. \& Kersters, K. (1996). Highresolution genotypic analysis of the genus Aeromonas by AFLP fingerprinting. Int J Syst Bacteriol 46, 572-580.

Huys, L., Dhert, P., Robles, R., Ollevier, F., Sorgeloos, P. \& Swings, J. (2001). Search for beneficial bacterial strains for turbot (Scophthalmus maximus L.) larviculture. Aquaculture 193, 25-37.

Ishimaru, K., Akagawa-Matsushita, M. \& Muroga, K. (1995). Vibrio penaeicida sp. nov., a pathogen of kuruma prawns (Penaeus japonicus). Int J Syst Bacteriol 45, 134-138.

Ishimaru, K., Akagawa-Matsushita, M. \& Muroga, K. (1996). Vibrio ichthyoenteri sp. nov., a pathogen of Japanese flounder (Paralichthys olivaceus) larvae. Int J Syst Bacteriol 46, 155-159.

Janssen, P. J. D. (2001). Selective restriction fragment amplification by AFLP. In New Approaches for the Generation and Analysis of Microbial Typing Data, pp. 177-210. Edited by L. Dijkshoorn, K. J. Towner \& M. Struelens. Amsterdam: Elsevier.

Kita-Tsukamoto, K., Oyaizu, H., Nanba, K. \& Simidu, U. (1993). Phylogenetic relationships of marine bacteria, mainly members of the family Vibrionaceae, determined on the basis of $16 \mathrm{~S}$ rRNA sequences. Int J Syst Bacteriol 43, 8-19.

Lambert, C., Nicolas, J. L., Cilia, V. \& Corre, S. (1998). Vibrio pectenicida sp. nov., a pathogen of scallop (Pecten maximus) larvae. Int $J$ Syst Bacteriol 48, 481-487.

Macdonell, M. T. \& Colwell, R. R. (1985). Phylogeny of the Vibrionaceae, and recommendation for two new genera, Listonella and Shewanella. Syst Appl Microbiol 6, 171-182.
Macián, M. C., Ludwig, W., Schleifer, K. H., Pujalte, M. J. \& Garay, E. (2001). Vibrio agarivorans sp. nov., a novel agarolytic marine bacterium. Int J Syst Evol Microbiol 51, 2031-2036.

Onarheim, A. M., Wiik, R., Burghardt, J. \& Stackebrandt, E. (1994). Characterization and identification of 2 Vibrio species indigenous to the intestine of fish in cold sea-water-description of Vibrio iliopiscarius sp. nov. Syst Appl Microbiol 17, 370-379.

Pitcher, D. G., Saunders, N. A. \& Owen, R. J. (1989). Rapid extraction of bacterial genomic DNA with guanidium thiocyanate. Lett Appl Microbiol 8, 151-156.

Pujalte, M.-J., Ortigosa, M., Urdaci, M.-C., Garay, E. \& Grimont, P. A. D. (1993). Vibrio mytili sp. nov., from mussels. Int $J$ Syst Bacteriol 43, 358-362.

Rademaker, J. L. W., Hoste, B., Louws, F. J., Kersters, K., Swings, J., Vauterin, L., Vauterin, P. \& de Brujin, F. J. (2000). Comparison of AFLP and rep-PCR genomic fingerprinting with DNA-DNA homology studies: Xanthomonas as a model system. Int J Syst Evol Microbiol 50, 665-677.

Raguénès, G., Christen, R., Guezennec, J., Pignet, P. \& Barbier, G. (1997). Vibrio diabolicus sp. nov., a new polysaccharide-secreting organism isolated from a deep-sea hydrothermal vent polychaete annelid, Alvinella pompejana. Int J Syst Bacteriol 47, 989-995.

Ring, E. \& Birkbeck, T. H. (1999). Intestinal microflora of fish larvae and fry. Aquac Res 30, 73-93.

Ring, E. \& Gatesoupe, F. J. (1998). Lactic acid bacteria in fish: a review. Aquaculture 100, 177-203.

Saitou, N. \& Nei, M. (1987). The neighbor-joining method: a new method for reconstructing phylogenetic trees. Mol Biol Evol 4, 406-425.

Sawabe, T., Sugimura, I., Ohtsuka, M., Nakano, K., Tajima, K., Ezura, Y. \& Christen, R. (1998). Vibrio halioticoli sp. nov., a nonmotile alginolytic marine bacterium isolated from the gut of the abalone Haliotis discus hannai. Int J Syst Bacteriol 48, 573-580.

Tamaoka, J. \& Komagata, K. (1984). Determination of DNA base composition by reversed-phase high-performance liquid chromatography. FEMS Microbiol Lett 25, 125-128.

Thompson, F. L., Hoste, B., Vandemeulebroecke, K. \& Swings, J. (2001). Genomic diversity amongst Vibrio isolates from different sources determined by fluorescent amplified fragment length polymorphism. Syst Appl Microbiol 24, 520-538.

Thompson, F. L., Hoste, B., Vandemeulebroecke, K., Engelbeen, K., Denys, R. \& Swings, J. (2002). Vibrio trachuri Iwamoto et al. 1995 is a junior synonym of Vibrio harveyi (Johnson and Shunk 1936) Baumann et al. 1981. Int J Syst Evol Microbiol 52, 973-976.

Urdaci, M. C., Marchand, M., Ageron, E., Arcos, J. M., Sesma, B. \& Grimont, P. A. D. (1991). Vibrio navarrensis sp. nov., a species from sewage. Int J Syst Bacteriol 41, 290-294.

Van Belkum, A., Struelens, M., De Visser, A., Verbrugh, H. \& Tibayrenc, M. (2001). Role of genomic typing in taxonomy, evolutionary genetics, and microbial epidemiology. Clin Microbiol Rev 14, $547-560$.

Vandamme, P., Segers, P., Ryll, M. \& 8 other authors (1998). Pelistega europaea gen. nov., sp. nov., a bacterium associated with respiratory disease in pigeons: taxonomic structure and phylogenetic allocation. Int J Syst Bacteriol 48, 431-440.

Willems, A., Doignon-Bourcier, F., Goris, J., Coopman, R., de Lajudie, P., De Vos, P. \& Gillis, M. (2001). DNA-DNA hybridization study of Bradyrhizobium strains. Int J Syst Evol Microbiol 51, 1315-1322.

Yumoto, I., Iwata, H., Sawabe, T., Ueno, K., Ichise, N., Matsuyama, H., Okuyama, H. \& Kawasaki, K. (1999). Characterization of a facultatively psychrophilic bacterium, Vibrio rumoiensis sp. nov., that exhibits high catalase activity. Appl Environ Microbiol 60, 67-72. 